\title{
A Miraculous Intrusion into This World: Thomas Pynchon's The Crying of Lot 49 as Postmodernist Detective Fiction
}

$\mathrm{B}$

efore discussing Lot $49^{1}$ as an example of postmodernist detective fiction, it is worth considering why detective fiction became such a popular form of expression among postmodernist writers. Firstly, the detective genre follows one of the main postulates of postmodernist fiction, namely that detective fiction provides the reader with a role of an active "coparticipant” or even "an accomplice" (Cortázar 1966: 397), to use Cortázar’s language, in the process of reading and the consequent constructing of meaning. The reader is given a possibility to collect and interpret clues, build the narrative and try to guess the figure of the criminal.

Secondly, postmodernist fiction, described by John Barth as the literature of exhaustion, is about the crisis of creativity after the modernist movement. In search of new forms, postmodernist writers turned to genres of the popular culture, such as detective fiction and science fiction, which were previously considered "low" genres. Formulaic and rule-bound, detective fiction opened a field for new experiments, connected both with the form and with the content of their stories.

Different critics define the new genre, which appeared as a result of the intrusion of postmodernist literature into detective fiction in different ways. Patricia Merivale and Susan Sweeney introduce the term "[a] metaphysical detective story" (Merivale \& Sweeney 2011:2), meaning "a text that parodies or subverts traditional detective story conventions [...] with an intention, or at least the effect, of asking questions about the mysteries of being and knowing which transcend the mere machinations of mystery plot" (Merivale \& Sweeney 2011: 2). The term seems inconsistent because postmodernism and metaphysics are fundamentally at odds

1 From this point onwards I will use the shorter form Lot 49 instead of The Crying of Lot 49. 
with each other. A similar definition, "metaphysical anti-detective" (Tani 1984: 40), is proposed by Stefano Tani, who underlines the transgression of the traditional detective codes. William V. Spanos, the first critic to connect the new genre to postmodernism, offers the term "anti-detective story" to describe the group of texts which aim to "evoke the impulse to 'detect'... in order to violently frustrate it by refusing to solve the crime" (V. Spanos qtd. in: Merivale \& Sweeney 2011:3). Although the 'anti-' definitions provided by Tani and Spanos properly specify the subversive nature of the genre, they reduce its complexity focusing only on its negational aspect. In contrast to them, Jamie Dopp prefers the more neutral term "postmodern detective" (94), suggesting that the texts of this genre "simultaneously exploit and undercut the received [detective] convention - a typically postmodern tendency" (Dopp 1997:108). Still, distinguishing between postmodernism, which relates to artistic expression, and postmodernity, the economic and cultural condition of society, it would be more accurate to name the genre postmodernist detective fiction. This definition is optimal because it is not limited to the negational aspect of the genre, used to subvert the conventions of the detective formula, but also combines the defining features of postmodernist poetics such as the usage of metafiction, mixing different genres, epistemological and ontological crises, inconsistencies of language and problems with mimetic representation of "reality".

Since the publication of Lot 49, many critics (see Tony Tanner and David Seed) noted that the structure of the novels is based on the detective genre. The paper focuses on postmodernist experimental approaches Pynchon employs to (de)construct the classic detective story and compare his strategies to the traditional detective formula.

The first aspect of the detective genre Pynchon plays with is the figure of a detective. In harmony with the traditional detective story where the detective is the central element, Oedipa Maas is the central character of Lot 49. Although there are some similarities between Oedipa Maas and the classic whodunit and hard-boiled detectives on the whole, the portrayal of Oedipa as the detective is significantly unconventional.

The first feature of the character that received a lot of critical attention is the peculiarity of the name. Oedipa is a female version of the Sophoclean Oedipus Rex, "the solver of riddle in one of the first detective stories in Western literature" (Tanner 1982: 60). By referring to the extratextual set of meanings, Oedipus Rex (429 BC), Pynchon establishes an intertextual connection that makes the reader perceive the novel through the lens of the detective genre and compare Oedipa Maas to the prototypical detective of the Western literature. The eponymous ancient tragedy tells the story of the king Oedipus, who conducts an investigation to find the person who murdered the previous king in order to rescue his country form the ravaging plague and, unaware that the person he is searching for is himself. The association evoked contrasting reactions from critics. On the one hand, Tony Tanner claims that Sophoclean Oedipus solves the riddle concerned with "his own parents, parricide and incest", which "in no way applies to Oedipa" (Tanner 1982: 60). On the other hand, Debra Moddelmog is certain that Oedipa's story parallels the story of Oedipus Rex (Moddelmog 1987: 248).

In addition to the intertextual link, the appearance of Oedipa differs from the image of the typical whodunit and hard-boiled detectives. Generally, detective fiction is a rule-bound genre and different detectives tend to possess similar qualities. So, as a personification of the whodunit detective and the point for comparison of the appearances, I choose Poe's August 
C. Dupin because he is the first widely recognized literary detective and a model for future followers. Dupin is an amateur detective, who tends to conduct the investigation himself, out of curiosity. He is usually accompanied by his less intelligent friend, who is the narrator of the story. In Poe's short stories, Dupin is described as an eccentric and extremely intelligent gentleman, who paradoxically combines sharp wit and creative imagination. The most characteristic feature of Dupin is his "peculiar analytic ability" (Poe 2006: 22) which is based on deep logical analysis of all possible sources of information and appliance of reason in order to recreate the chronology of the events leading to a crime.

Sam Spade, the influential character of Maltese Falcon (1930) by Dashiell Hammett, is chosen as the personification of the American hard-boiled detectiveSpade is a professional private eye that works alone. As the name of the sub-genre indicates, he is hard-boiled and athletic, representing the stereotypical image of masculinity. He is smart but instead of deduction he opts for plainness, mental and physical toughness which provide the story with more plot action (Scaggs 2005: 61).

Although Oedipa shares some minor characteristics with both the classic whodunit and the hard-boiled detectives, the general portrayal of Oedipa as a detective differs sharply. To start with, Pynchon's choice of the female detective is unusual. From the birth of the genre and at least by the 1960s, with few exceptions, both the whodunit and hard-boiled detectives have been predominantly male. Furthermore, it is interesting to note that Pynchon does not attempt to present Oedipa as an exceptional individual, as were Dupin or Spade. On the contrary, Oedipa Maas is a typical representative of the American society of the 1960s. Through an indirect description of her environment, the reader gets to know that Oedipa is a stereotypical middle-class housewife, whose routine consists of working in the garden, watching TV, shopping in supermarkets, and visiting Tupperware parties. She is not hired as a professional detective, nor does she decide to take the case herself. Thus, getting involved in an undertaking underlies the discrepancy of her being the detective, " $[s]$ he [Oedipa] had never executed a will in her life, didn't know where to begin, didn't know how to tell the law firm in LA that she didn't know where to begin" (Pynchon 2000: 3).

Comparing her to the whodunit and hard-boiled detectives, Oedipa Maas is closer to the detective of the American tradition. She compensates the lack of intelligence and experience with persistence and actions, determinedly pursuing her goal. Yet, there is a substantial difference in the complexity of their characters. While the hard-boiled detective, like Sam Spade, is rather a rule-bound flat character with a guaranteed success of his investigation and, consequently, a stable identity, Oedipa Maas is a round character, whose identity changes throughout her quest and whose success is relative if not obscure. At the beginning of the novel, Oedipa considers her middle-class environment as an enclosure and feels herself a "prisoner among the pines and salt fogs of Kinneret" (Pynchon 2000: 11). Later on, Oedipa gets enthusiastic about her quest and expects that "object behind her discovery of what she was to label the Tristero [...] were to bring to an end her encapsulation in her tower" (Pynchon 2000: 29). As the adventure progresses, it becomes clear that Oedipa loses control over the investigation, "Lest, possibly, it [Trystero] grow larger than she and assume her into itself" (Pynchon 2000: 128). In the fifth chapter, after the night of hallucination, an exhausted Oedipa falls into despair and paranoia. As a result, she develops alcohol addiction and experiences health problems: "Her attention span could often be measured in seconds, and she laughed nervously more than she spoke. Waves of nausea, lasting five or ten minutes, would strike her at random, 
cause her deep misery, then vanish as if they had never been" (Pynchon 2000: 132). Finally, she abandons her investigation, "Having begun to feel reluctant about following up anything" (Pynchon 2000: 127-128). By the end of the novel, Oedipa visits the auction, where she is supposed to find out the truth about the Trystero. Yet, the crying of lot 49 and the following denouement are left outside of the story. So, if the main criterion of the success of the private eye is the accomplishment of the mission, Oedipa fails as a detective.

This leads to the most characteristic distinction between Lot 49 and classic detective fiction - the question of knowledge. Both the whodunit and the hard-boiled detectives are famous for their deductive approach, which leads to a successful unraveling of the mystery. In contrast to them, Oedipa's quest for meaning is spoilt by the information overload, which results into her experiencing an epistemological crisis. As the true private eye, Oedipa starts her inquiry with the intention of "sorting it all out" (Pynchon 2000: 3), which turns out to be an impossible mission due to the excessive amount of data. Charles Baxter notes that, "Sorting' implies clear categories, and categories suggest some kind of sure epistemological methodology; but there is no such certainty here, not even the suggestion of one" (Pynchon 2000: 28). The problem is that clues Oedipa receives are not red herrings, on the contrary, they are too obvious and fit into patterns too easily, which makes the story more perplexing and intricate, "[t]hat's what would come to haunt her most, perhaps: the way it fitted, logically, together. As if [...] there were revelations in progress all around her" (Pynchon 2000: 29). Oedipa's dilemma is that while being constantly bombarded with new information, she does not have enough time to organize it properly - the story unfolds too fast.

Another element that is redefined in Lot 49 is the portrayal of the villain. In both the classic whodunit and hard-boiled detective stories, the criminal is usually portrayed as an eerie mastermind. This serves two functions: firstly, it brings scale to the crime. Secondly, the villain is used as a foil to the detective. Pynchon's portrayal of the villain in Lot 49 is quite unconventional. The cryptic aura of the Trystero is created through its absence. Although Oedipa encounters various traces of the Trystero, she never sees it directly. The important feature that contributes to the mystery of the Trystero is its impersonality - it is an organization but none of its members are directly introduced in the novel. Moreover, it is never sure if it exists at all. Everything the reader and Oedipa know about the Trystero is conveyed through hints, shadows, absence, and silence.

Another important element of the classic detective fiction Pynchon subverts is the structure. According to Tzvetan Todorov, the classic detective story has a two-fold structure, meaning it consists of two unconnected stories. The first one is the story of the crime and the second the story of the investigation (Todorov 1977: 44). Formally, the structure of Lot 49 corresponds to the two-fold structure, containing the story of the mystery and the story of the investigation. For the British tradition the fundamental part is the story of the crime, while for the American the main part remains that of the investigation. In these terms, Lot 49 is closer to the American tradition. Yet, the principal difference between Lot 49 and the classic detective story lies is in the direction of the mystery, as Tanner explains: "With a detective story you start with a mystery and move towards a final clarification [...] whereas in Pynchon's novel we move from a state of degree-zero mystery [...] to a condition of increasing mystery and dubiety" (Tanner 1982: 56). The novel starts on the ordinary summer day in Southern California and it is not until the third chapter when " $[\mathrm{t}]$ he things $[. .$.$] did not$ delay in turning curious" (Pynchon 2000:29). Yet, the most frustrating element of the novel's 
structure is the ending or rather the lack of it. The defining feature of the detective genre lies in the denouement, in the final unveiling of the riddle, which relieves the reader of ignorance. Lot 49, in its turn, radically resists closure and finishes with an open ending, Oedipa's waiting for the crying of lot 49. Rather than offering resolution to the intricacies of the plot, the ending confuses the reader even further.

In addition to the play with the structural elements, Lot 49 also conducts interesting experiments in relation to space. Frederick Jameson in his definition of the postmodern city argues that its main feature is a lack of a fixed center (Jameson 1991: 88). This concept finds its expression in the urban space of San Narciso. Lacking a center that would provide a structure, the city is identified by Oedipa as a number of separated parts, which only pretend to preserve coherence, "[1]ike many named places in California it [San Narciso] was less an identifiable city than a grouping of concepts" (Pynchon 2000: 12). Surrounded by a multitude of different signs, Oedipa feels the textual nature of San Narciso and reads it as a text. In the eyes of the detective, everything in San Narciso is interpreted as a potential clue; she looks for "outward patterns a hieroglyphic sense of concealed meaning, of an intent to communicate” (Pynchon 2000: 13).

Richard Lehan, in turn, associates the postmodern city with the labyrinth (Lehan 1986: 110) which is a recurring image throughout Lot 49. Firstly, it is manifested in the labyrinthlike construction of space: Oedipa compares the "gently curving streets of San Narciso" to the "curving" (Pynchon 2000: 76) corridors of Berkeley hills hotel. Secondly, the image of the labyrinth stands as a metaphor for mental confusion that Oedipa experiences during her fruitless quest, which finds its reflection in the trajectory of her journey. The geography of her quest among the streets of Kinneret, whose name signifies 'circuit' in Hebrew (Kolbuszewska 2000: 91), has a circular form - Oedipa begins and ends with John Nefastis' apartment: "She was back where she'd started, and could not believe 24 hours had passed" (Pynchon 2000: 99).

The image of a labyrinth reflects not only the state of Oedipa's mental struggles and the spatial organization of the city but also the style of narration. The narrator of the whodunit detective story is the assistant of the detective, who tells the story in a balanced and precise tone. The narration of the hard-boiled detective is usually of the objective third person that reflects the tough mentality of the private eye. The language is dry and vernacular, recording faithfully the chronology of the events. The language of Lot 49, in contrast, reflects the postmodernist poetics and subverts the style of narration both of whodunit and hard-boiled fiction. Namely, it demonstrates the complexity of language and difficulties with the representation of "reality". The course of the events is difficult to follow; the language is mazy and fragmentary; the passages are imbalanced and dense with details. Moreover, there are a lot of extratextual references to other works of literature, science and the pop culture of the mid-1960s.

All in all, it may be concluded that in Lot 49 Pynchon evidently subverts the conventions of both the whodunit and hard-boiled detective genres. His experiments concern the portrayal of the detective and his method, the order of the plot, the narrative style, the setting, and finally the image of the villain. Instead of the masculine and reasoning machine, Pynchon makes the detective the middle-class housewife of the American 1960s. Under the detective method, Pynchon masks his considerations on the epistemological crisis that became central to the age of postmodernism. Leaving the conformist Californian suburbia, Oedipa falls into 
bizarre adventures, wandering through the urban labyrinth of the fictional San Narciso. In place of the crime and the villain, Oedipa unravels the history of the mysterious postal organization from medieval Europe discovering an alternative version of the history of Europe and America.

ROMAN VASYLENKO

(iD) https://orcid.org/0000-0003-4205-0850

Magister literaturoznawstwa Uniwersytetu Marii Curie-Skłodowskiej. Swoje zainteresowania badawcze skupia wokół literatury pięknej postmodernistycznej, szczególnie wokół pisarzy -

Thomasa Pynchona i Stephena Wrighta.

Kontakt: roman.vasylenko44@gmail.com

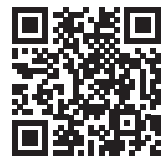




\section{Bibliography}

Cortázar Julio (1966), Hopscotch, trans. G. Rabassa, Pantheon Books, New York.

Dopp Jamie (1997), Affirming the Mystery in Eric McCormack's 'The Mysterium', "Canadian Literature", no 154.

Grant Kerry (2008), A Companion to The Crying of Lot 49, The Second Edition, The University of Georgia Press, Athens.

Jameson Frederick (1991), Postmodernism, or, the Cultural Logic of Late Capitalism, Duke UP, Durham.

Kolbuszewska Zofia (2000), The Poetics of Chronotope in the Novels of Thomas Pynchon, The Learned Society of the Catholic UP, Lublin.

Lehan Richard (1986), Urban Signs and Urban Literature: Literary Form and Historical Process, "New Literary History", vol. 18, no.1, Studies in Historical Change, (Autumn), p. 99-113.

Merivale Patricia, Susan Elizabeth Sweeney (2011), Detecting Texts: The Metaphysical Detective Story from Poe to Postmodernism, University of Pennsylvania Press, Philadelphia.

Moddelmog Debra A. (1987), The Oedipus Myth and Reader Response in Pyn-chon's The Crying of Lot 49, "Papers on Language and Literature" 23.2.

Poe Edgar Allan (2006), The Murders in the Rue Morgue [in:] The Portable Edgar Allan Poe, ed. Kennedy J.G., Penguin Books, New York.

Pynchon Thomas (2000), The Crying of Lot 49, Vintage Books, London.

Scaggs John (2005), Crime Fiction, Routledge, London-New York.

Seed David (1988), The Fictional Labyrinths of Thomas Pynchon, The Macmillan Press LTD, London.

Tani Stefano (1984), The Metafictional Anti-Detective Novel [in:] The Doomed Detective: The Contribution of the Detective Novel to Postmodern American and Italian Fiction, Southern Illinois UP, Carbondale.

Tanner Tony (1982), Thomas Pynchon, Methuen, London-New York.

Todorov Tzvetan (1977), The Typology of Detective Fiction [in:] The Poetics of Prose, trans. R. Howard, Cornell UP, NY: Ithaca.

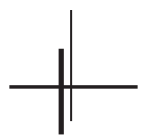

